\title{
Effects of Lactose in Saline Infusion on Electrolyte Alterations in Trypanosoma vivax-Infected Cattle
}

\author{
Kwem B. Kadima, ${ }^{1}$ Ismaile A. UMAR, ${ }^{2}$ James J. OMAGE, ${ }^{2}$ I.O. IgBoKwe, ${ }^{1}$ \\ Najume D.G. IBRAHIM, ${ }^{1}$ Erastus O. GYANG ${ }^{3}$ Daniel I. SAROR, ${ }^{1}$ \\ and King A.N. EsIEVO ${ }^{1, *}$ \\ ${ }^{1}$ Department of Veterinary Pathology and Microbiology, \\ ${ }^{2}$ Department of Biochemistry, and \\ ${ }^{3}$ Department of Veterinary Surgery and Medicine, \\ Ahmadu Bello University, Zaria, Nigeria
}

(Received August 25, 1998)

Summary Alteration of serum electrolytes $\left(\mathrm{Na}^{+}, \mathrm{K}^{+}, \mathrm{Cl}^{-}\right.$, and $\mathrm{HCO}_{3}{ }^{-}$) was studied in Zebu cattle experimentally infected with $11.0 \times$ $10^{6}$ Trypanosoma vivax. Another group of similarly infected cattle was intravenously infused with lactose in normal saline, at a dose rate of 0.5 $\mathrm{g} / \mathrm{kg}$ body weight as a function of the animal blood volumes of about 6$7 \%$ their body weights. Serum $\mathrm{Na}^{+}$and $\mathrm{Cl}^{-}$concentrations showed significant $(p<0.05)$ increases following decreasing parasitemia on days 6,7 , and 8 post infection (p.i.), whereas the greatest drops, resulting in hyponatremia and hypochloremia, occurred at the period when parasites were very scant in the blood. The $\mathrm{Na}^{+}$and $\mathrm{Cl}^{-}$returned to normalcy between days 10 and 13 p.i., coinciding with the second parasitemic wave. $\mathrm{K}^{+}$values showed a nonsignificant decline following the decline of parasitemia, and rose to normal values thereafter, around the second wave of parasitemia. The $\mathrm{HCO}_{3}{ }^{-}$values were lowest when the parasites became numerous in the blood on day 3 p.i., with a significant $(p<0.05)$ decrease at peak parasitemia on day 5 p.i. Subsequently, $\mathrm{HCO}_{3}{ }^{-}$concentrations increased when parasites became low in number in the peripheral circulation; thereafter, interrupted but significant $(p<0.05)$ increases in $\mathrm{HCO}_{3}{ }^{-}$values occurred as the disease progressed. With the i.v. infusion of lactose in normal saline when the disease had been established, evidenced by peak parasitemia and declining packed cell volume (PCV), serum $\mathrm{Na}^{+}$and $\mathrm{Cl}^{-}$remained normal as observed in the first uninfected uninfused group. The variations of $\mathrm{K}^{+}$and $\mathrm{HCO}_{3}{ }^{-}$showed a similar pattern during the infusion. The values of all four electrolytes were relatively reduced immediately after and during the course of the infu-

* To whom correspondence should be addressed. 
sion. The anion gaps were $20-22 \mathrm{~mm} /$ liter for the uninfected group; $22-25$ $\mathrm{mm} /$ liter on days 3-5 p.i. and 16-19 mM/liter on days 6-13 p.i. for the infected, uninfused group. Whereas infusion into the infected group produced an anion gap of $18-25 \mathrm{~mm} /$ liter. The choice of saline as a solvent for lactose and the total infusion volume had no detrimental effect on the host's electrolytes and acid-base status; rather, the infusion ameliorated the aberrations in electrolytes associated with $T$. vivax in cattle.

Key Words: cattle, trypanosomiasis, electrolytes, lactose, saline

Over a decade ago the production of the potent enzyme antigen, sialidase, had been ascribed to Trypanosoma vivax [1,2], T. cruzi [3], and $T$. rangeli [4], was reported, and alterations of the host's sialoglyco conjugates by this potent enzyme was incriminated in the pathogenesis of cattle trypanosomiasis [5] and of human Chagas disease [6]. The various biochemical differences existing in the erythrocyte sialoglyco conjugates of the trypanotolerant Ndama and the trypanosusceptible Zebu cattle [7-9] gave further credence to the relative trypanotolerance of the former and the significance of the trypanosome sialidases and the host sialoglycoconjugates in the pathophysiology of the anemia of bovine trypanosomiasis, as earlier reviewed [10].

Recent studies have shown that the sialidase cleavage of erythrocytic sialic acids during the course of bovine trypanosomiasis [5], lead to the exposure of the penultimate B-galactosyl residues on the erythrocytic membrane [11, and Omage, J.J. et al., 1997, personal communication] and enhanced activities of the Kupffer cells' surface lectins that bind to the desialylated erythrocytic membrane galactose, hence resulting in phagocytosis and sequestration of the desialylated red cells [12]. These latter processes can be inhibited by lactose, thus supporting lactose as a base for a trypanocidal agent. For these reasons, the kinetics of intravenously infused lactose in cattle [13] and the effects of $T$. vivax infection on the lactose kinetics were established $[14,15]$. The volume of lactose in normal saline infusion made it imperative to investigate the effects of the infusion on the electrolytes in cattle T. vivax infection, as reported herein.

\section{MATERIALS AND METHODS}

Experimental animals. Twelve male Zebu breed (Sokoto Gudali) yearlings aged 12-18 months and weighing 70-90 kg were purchased from Talata Mafara (Sokoto State of Nigeria), an area known to be tse-tse fly free. These animals were housed within the premises of the Faculty of Veterinary Medicine, in Ahmadu Bello University, Zaria, and screened for helminthiasis, hemo- and ectoparasites; they were dewormed with thiabendazole (Merck, Sharp, Dohme Ltd., U.K.); 
vaccinated against anthrax, blackquarter, contagious bovine pleuropneumonia, and rinderpest and sprayed with chlorfenviphos (pfizona ${ }^{\circledR}$, Pfizer Nigeria Ltd.) as a treatment against ticks.

The animals were fed hay supplemented with a mixture of cotton seed cake and wheat offals; water and salt licks were supplied ad libitum. The animals were acclimatized for about 1 month before the commencement of the experiment.

Parasites and infection. A stock of $T$. vivax was isolated from a pregnant cow with a pure natural infection in Samaru, Zaria, and identified. Two milliliters of the infected blood was used to infect a Sahel brown goat which served as a donor animal for the experimental yearlings, after the goat had developed its massive first parasitemia.

The twelve yearlings were divided into 3 groups of 4 each, marked A, B, and $\mathrm{C}$ and housed separately. Animals in group A served as the uninfected control, whereas groups $B$ and $C$ animals were infected by jugular venipuncture with $5 \mathrm{ml}$ of infected donor goat's blood containing about $11.0 \times 10^{6}$ trypanosomes.

Lactose infusion. Parasitemia was monitored in groups $\mathrm{B}$ and $\mathrm{C}$ by the micro-hematocrit, wet mounts, and hemocytometer methods. At the peak of parasitemia, when the disease had been established (further confirmed by the decline in packed cell volume (PCV)), each of the cattle in group $\mathrm{C}$ was given lactose in normal saline intravenously at the dose rate of $0.5 \mathrm{~g} / \mathrm{kg}$ body weight daily at the rate of $18 \mathrm{ml} / \mathrm{min}$; the lactose (in saline) was given as a function of the animal's weight, their blood volume being about $6-7 \%$ of their body weight as outlined by Umar et al. [13-15].

Sample collection. Five milliliters of blood was collected daily from the cattle in groups $\mathrm{A}, \mathrm{B}$, and $\mathrm{C}$, through the jugular vein into vacutainers with ethylene diamino tetra-acetate (EDTA) as anticoagulant for routine hematology and estimation of parasitemia. From groups A, B, and C animals, another set of blood ( $5 \mathrm{ml}$ each) was collected by jugular venipuncture into vacutainers without anticoagulant; serum was harvested from clotted blood within an hour of collection by centrifugation $(200 \times \mathrm{g} / 15 \mathrm{~min})$ and immediately stored at $-20^{\circ} \mathrm{C}$ prior to analysis.

Estimation of parasitemia. Trypanosomes were detected in the blood samples by the micro-hematocrit centrifuge technique, and the parasitemia score was estimated as described by Woo [16]. The trypanosomes seen in the buffy coat area of the hematocrit were counted, and the parasitemia scores were given as $1+$ (occasional trypanosomes), $2+$ (1-2 trypanosomes), $3+$ (3-20 trypanosomes), and $4+(>20$ trypanosomes $)$.

Serum electrolyte analysis. Serum sodium $\left(\mathrm{Na}^{+}\right)$and potassium $\left(\mathrm{K}^{+}\right)$were analyzed by flame photometry; whereas the serum chloride $\left(\mathrm{Cl}^{-}\right)$level was analyzed by the method of Schales and Schales [17], and serum bicarbonate $\left(\mathrm{HCO}_{3}{ }^{-}\right)$, by the titrimetric method outlined by Monica [18].

Statistical analysis. Student's $t$ test was used, and values of $p<0.05$ were considered significant.

Vol. 27, No. 1, 1999 
Anion gap principle. Anion gap principle, defined as the difference between commonly measured cations and anions $\left[\mathrm{Na}^{+}+\mathrm{K}^{+}\right]-\left[\mathrm{Cl}^{-}+\mathrm{HCO}_{3}^{-}\right][19]$ was used, and values less or greater than $19-20 \mathrm{~mm} /$ liter were considered of significance.

\section{RESULTS}

\section{Parasitemia}

Parasites were first detected in the blood of the infected cattle on day 2 p.i., with peak parasitemia occurring on day 5 p.i., which peak was followed by a decline on day 6 p.i. and disappearance of parasites from the circulation on days 7 and 8 p.i. Parasites reappeared in the circulation on day 9 p.i. and approached a second peak on day 13 p.i. when the samplings were terminated (Fig. 1a).

In the infected infused group, the parasites appeared on day 2 p.i., peaked on day 5 p.i., and decreased on day 6 p.i., but remained in circulation at very low levels on days 7 p.i. to 10 p.i. Subsequently parasitemia approached a second peak on day 13 p.i. (Fig. 1b).

\section{Serum electrolytes changes}

Serum $\mathrm{Na}^{+}$levels were within normal values on days 3,4 , and 5 p.i., but significantly $(p<0.05)$ increased on days 6 and 7 p.i. following the decreases and disappearance of parasites from the blood. Thereafter, a decrease occurred on days 8 p.i., producing hyponatremia on day 9 p.i. Subsequently $\mathrm{Na}^{+}$levels increased to normal levels on days 11,12 , and 13 p.i., coinciding with the second parasitemic wave (Fig. 1a).

In the infected and infused group $\mathrm{C}$ animals, $\mathrm{Na}^{+}$values were within normal levels on days 3,4 , and 5 p.i., and significantly $(p<0.05)$ increased on day 6 p.i; but they subsequently decreased to remain within the normal range during lactosein-saline infusion on days 6 to 10 p.i., and then increased slightly but not above normal values on days 11,12 , and 13 p.i. (Fig. 1b). Changes in serum $\mathrm{Cl}^{-}$values expectedly followed the same pattern as serum $\mathrm{Na}^{+}$in both groups (Fig. 1a and b).

Serum $\mathrm{K}^{+}$levels were within the normal range on days $3,4,5$, and 6 p.i. but significantly $(p<0.05)$ decreased on days 7,8 , and 9 p.i., also coinciding with the decline and disappearance of parasites from the circulation. Subsequently a gradual increase from day 10 p.i. to normal levels on days 12 and 13 p.i. was observed as the second parasitemic wave built up (Fig. 1a).

In the infected and infused group $\mathrm{C}$ animals, serum $\mathrm{K}^{+}$levels were normal on days 3, 4, and 5 p.i. Serum $\mathrm{K}^{+}$levels remained non-significantly lower than those of the uninfected uninfused animals. After infusion $\mathrm{K}^{+}$values varied in accordance with the second wave of parasitemia (Fig. 1b).

Serum $\mathrm{HCO}_{3}{ }^{-}$levels were non-significantly lower on days 3, 4, 5, and 6 p.i., but gradually increased on days 7,8 , and 9 p.i. to within normal values. Subsequently intermittent significant $(p<0.05)$ increases on days 10,11 , and 12 p.i. were 

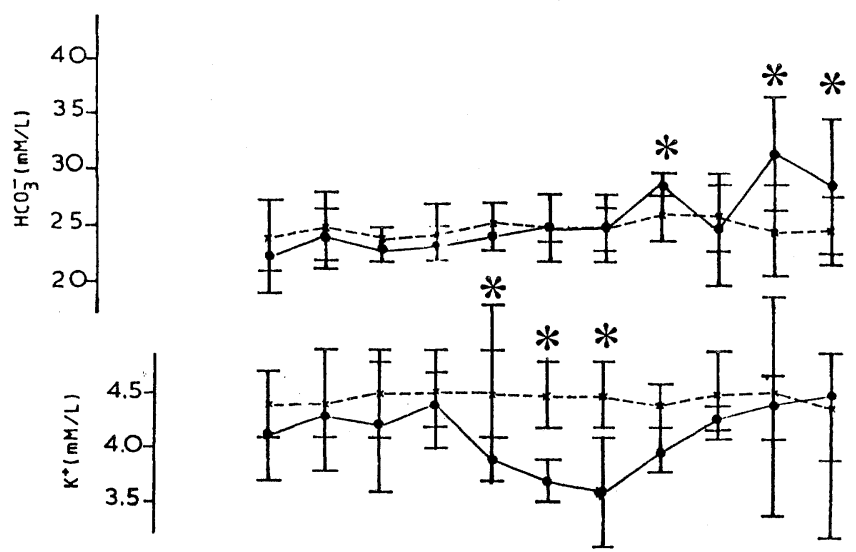

105-

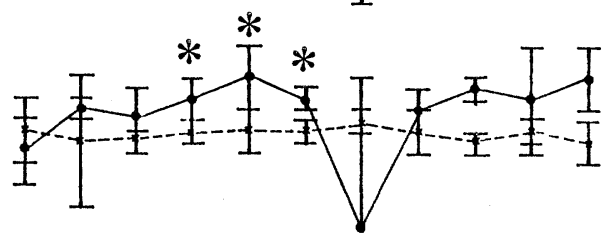

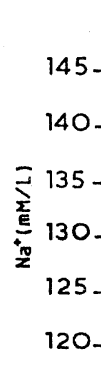

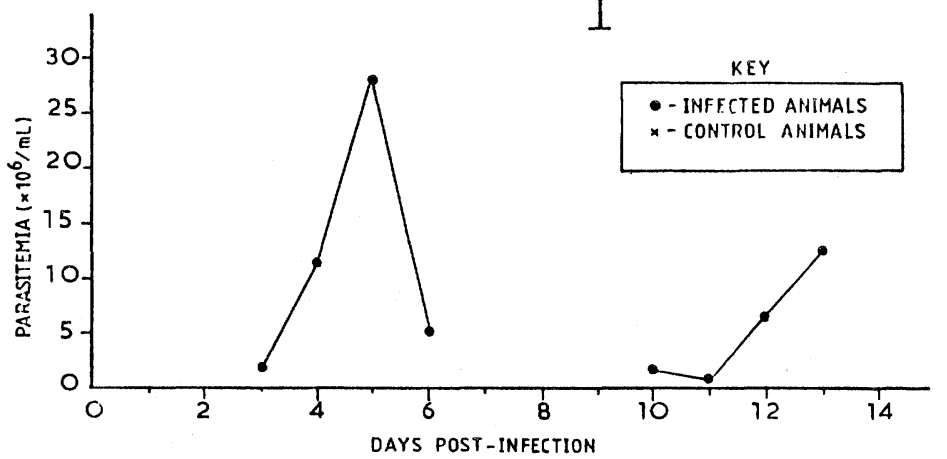

Fig. 1(a)

Fig. 1. Effect of T. vivax infection (a) and lactose-in-saline infusion (b) on serum electrolytes values $\left(\mathrm{Na}^{+}, \mathrm{Cl}^{-}, \mathrm{K}^{+}, \mathrm{HCO}_{3}^{-}\right)$in relation to $T$. vivax parasitemia. ${ }^{*}$ Areas of significant differences. 


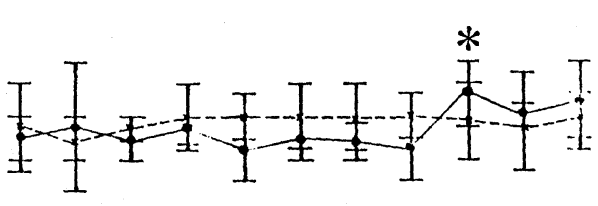

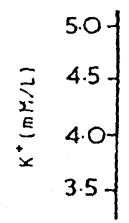

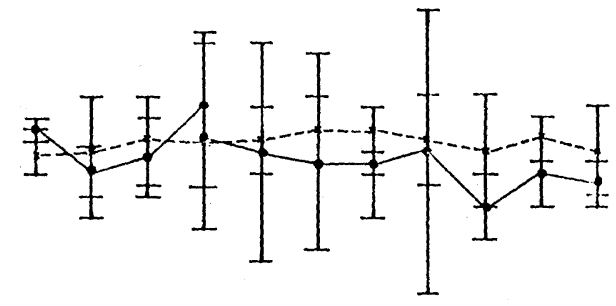

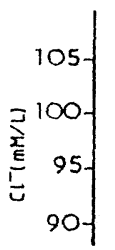

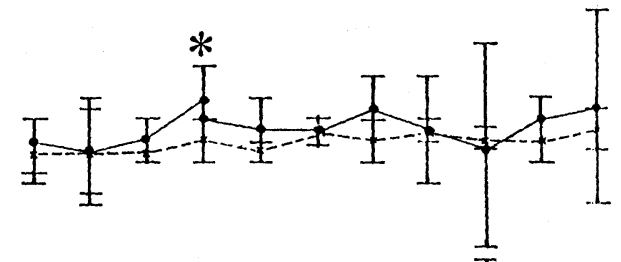

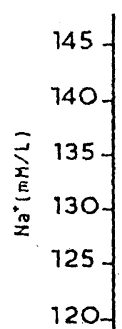
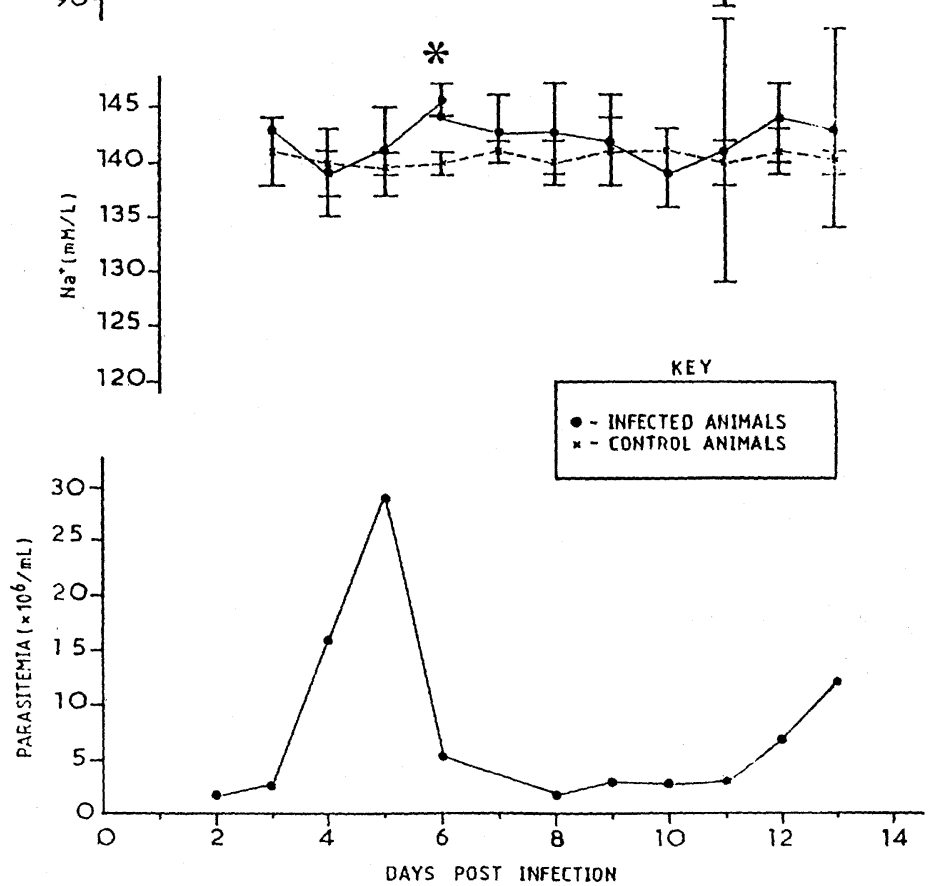

Fig. 1(b) 
seen as the second parasitemic wave arose (Fig. 1a).

For the infected and infused group $\mathrm{C}$ animals, serum $\mathrm{HCO}_{3}{ }^{-}$values were within the normal range on days 3 to 6 p.i. but were significantly $(p<0.05)$ lower on days 7 to 10 p.i. during the lactose-in-saline infusion. This was followed by significant $(p<0.05)$ increases on days 11 and 13 p.i. as the second parasitemic wave occurred (Fig. 1b) when lactose-in-saline was not infused.

All four electrolytes showed immediate decreases in values upon commencement of lactose-in-saline infusion on day 6 p.i. (Fig. 1b).

\section{Anion gap}

Uninfected control animals showed a gap of 20-22 mm/liter. Infected uninfused animals had an anion gap of $22-25 \mathrm{~mm} /$ liter on days 3 to 5 p.i. and a decline to between 16-19 mM/liter as the disease progressed. For the infected and infused group $\mathrm{C}$ animals, on days 3 to 5 p.i. the anion gap was $20-25 \mathrm{~mm} /$ liter, but declined during the infusion days (6 to 10 p.i.) from the 25 to $18 \mathrm{~mm} /$ liter and remained within 18 to $22 \mathrm{~mm} /$ liter on days 12 and 13 p.i.

\section{DISCUSSION}

Infection with $T$. vivax caused an acute disease in the cattle with a very short prepatent period probably due to the high infective dose of the parasites [20]. At the onset of the first parasitemia, the four electrolytes of the infected hosts were maintained within the normal range (Fig. 1a).

The significant $(p<0.05)$ increases in $\mathrm{Na}^{+}$and $\mathrm{Cl}^{-}$following the decrease and disappearance of parasites from the circulation suggest a possible secretion of these electrolytes into the plasma by dying and/or dead trypanosomes. Also a possible Na-pump modulation might have occurred with increasing parasitemia, leading to the inability of the kidneys to control electrolytes. In support of the latter is the observation of a decrease in $\mathrm{Na}^{+}-\mathrm{K}^{+}$ATPase activity with increasing parasitemia in $T$. congolense-infected rats, leading to modulation of the Na-pump [21]. The observed gradual increases in $\mathrm{Na}^{+}, \mathrm{K}^{+}$, and $\mathrm{Cl}^{-}$to slightly above normal values, coinciding with the second parasitemic wave, strongly gives credence to the causal relationship between the level of parasitemia, and their metabolic activities directly or indirectly through Na-pump modulation of the host, in affecting the electrolyte and acid-base status of the $T$. vivax-infected cattle. Since the excretion, absorption and distribution of chloride are passive, usually accompanying sodium, which is actively transported [22], the similarity in variations of $\mathrm{Na}^{+}$and $\mathrm{Cl}^{-}$ during this study is explainable.

The decreases in $\mathrm{Na}^{+}$and $\mathrm{Cl}^{-}$on day 8 p.i. and the sharp drops on day 9 p.i. to a point of hyponatremia and hypochloremia, may have been due to a diversion of the excess $\mathrm{Na}^{+}$and $\mathrm{Cl}^{-}$into other body compartments. Particularly, intracellularly in an attempt to control their excesses in circulation, but one would have expected a concomitant increase in plasma $\mathrm{K}^{+}$at this period. The observed 
decreases in plasma $\mathrm{K}^{+}$, which coincided with the slight increases in the $\mathrm{HCO}_{3}^{-}$ levels, indicate an existing metabolic alkalosis, during this period, due to $\mathrm{Cl}^{-}$loss [22]. In chloride loss alkalosis, the apparent $\mathrm{Cl}^{-}$deficit causes the kidneys to increase $\mathrm{Na}^{+}$exchange, and $\mathrm{H}^{+}$moves extracellularly to generate an equal amount of $\mathrm{HCO}_{3}{ }^{-}$. Thus the body tries to maintain extracellular fluid volume by increasing $\mathrm{Na}^{+}-\mathrm{K}^{+}$exchange resulting in $\mathrm{K}^{+}$depletion and the concomitant aciduria frequently observed in metabolic alkalosis $[23,24]$.

In group $\mathrm{C}$ cattle the plasma electrolyte changes during the days of lactose infusion showed normal levels for $\mathrm{Na}^{+}$and $\mathrm{Cl}^{-}$, while $\mathrm{HCO}_{3}{ }^{-}$and $\mathrm{K}^{+}$were below normal levels, further indicating that the existing metabolic alkalosis with the disease may be due partly to $\mathrm{K}^{+}$depletion, which did not respond completely to normal saline infusion in this study, as is expected in simple $\mathrm{Cl}^{-}$loss alkalosis [23].

Applying the principle of the anion gap, defined as the difference between commonly measured cations $\left(\mathrm{Na}^{+}+\mathrm{K}^{+}\right)$and anions $\left(\mathrm{Cl}^{-}+\mathrm{HCO}_{3}^{-}\right)$[19] to further evaluate the acid-base status of these animals during the $T$. vivax infection and lactose-in-saline infusion, the anion gap for the control was between 20-22 mM/ liter. The anion gap for infected uninfused was $22-25 \mathrm{~mm} /$ liter on days 3 to $5 \mathrm{p}$.i. as parasitemia built up, indicating an existing metabolic acidosis early in the disease, since metabolic acidosis is associated with a normal or increased anion gap [25]. Metabolic acidosis in trypanosomiasis is associated with organ and tissue damages [26-29]. Therefore one may surmise that metabolic acidosis early in this experiment when no severe organic damages had occurred, might have been due to a combination of the following factors: increase in parasitemia, accompanied by decreased PCV, hence decreased oxygen-carrying capacity of red blood cells to tissues, causing severe hypoxia that enhanced glycolysis and liberation of lactic acid [19]. This is plausible since an increase in the anion gap has been associated with increased concentrations of unmeasured organic acids (lactate and ketones) and inorganic acids (sulfates and phosphates) [30,31]. The decline in the anion gap to between 16 and $19 \mathrm{~mm} /$ liter on days 7,8 , and 9 p.i. due to decreased cation values further supports the above suggestion of existing metabolic alkalosis at this period and metabolic alkalosis in cattle due to deficient cations, placing limits on the kidney to regenerate acid-base balance has been reported [24].

In the infected and infused group $C$ animals the anion gap was $22-25 \mathrm{~mm}$ / liter, prior to infusion from days 3 to 5 p.i. (similar to infected uninfused group at this period) but lactose-in-saline infusion caused a drop from $25 \mathrm{~mm} /$ liter on day 7 p.i. to $18 \mathrm{~mm} /$ liter on day 10 p.i., a variation similar to that is the uninfected uninfused controls. However the gap remained between 18 and $22 \mathrm{~mm} /$ liter as the second parasitemia built up.

Therefore it is pertinent to surmise that in acute $T$. vivax infection of cattle there is an early metabolic acidosis, followed by metabolic alkalosis due to depletion of $\mathrm{Cl}^{-}$and $\mathrm{K}^{+}$. The choice of saline as a solvent for lactose and the total volume infused had no detrimental effect on the hosts' electrolyte and acid-base 
status. Rather the infusion ameliorated the electrolytes aberrations associated with T. vivax infection in cattle, probably by expanding the extracellular fluid volume with chloride [31, 32] and producing a near normal anion gap, as observed in this study. However the addition $\mathrm{K}^{+}$to the lactose saline solution would be beneficial, if lactose is to be considered as a base for a trypanocidal drug [11, 12-14].

Financial support of the Ahmadu Bello University Board of Research and of the E.E.C, Lome III Trypanosomiasis Project in Nigeria is gratefully acknowledged.

\section{REFERENCES}

1. Esievo, K.A.N. (1979): In vitro production of neuraminidase (sialidase) by Trypanosoma vivax. Proceeding of the 16th Meeting of the OAU/STRC International Council for Research and Control; Yauonde, Cameroun, October 29th-November 3rd, pp. 205-210.

2. Esievo, K.A.N. (1983): T. vivax, stock v953: Inhibition effect of type A influenza virus anti-HAV8 serum on in vitro neuraminidase (sialidase) activity. Parasitology, 69, 491-495.

3. Pereira, M.E.A. (1983): A developmentally regulated neuraminidase activity in $T$. cruzi. Science, 219, 1444-1446.

4. Reuter, G., Pereira, M.E.A., and Schauer, R. (1984): Isolation and characterisation of a sialidase from Trypanosoma rangeli. Carbohydrates, in Abstracts of the XIIth International Carbohydrate Symposium. July 1-7, ed. by Viegenthart, J.P.G., Kamerling, J.P., and Veldink, G.A., Vonk Publishers, Amsterdam, 311 pp.

5. Esievo, K.A.N., Saror, D.I., Ileomobade, A.A., and Hallaway, M.H. (1982): Variation in erythrocyte surface and free serum sialic acid concentration during experimental Trypanosoma vivax infection in cattle. Res. Vet. Sci., 32, 1-5.

6. Pereira, M.E.A., and Hoff, R. (1986): Heterogenous distribution of neuraminidase activity in strains and clones of $T$. cruzi and its possible association with parasite myotropism. Mol. Biochem. Parasitol., 20, 183-189.

7. Esievo, K.A.N., Saror, D.I., Kolo, M.N., and Eduvie, L.O. (1986): Erythrocyte sialic acids concentrations in Ndama and Zebu cattle. J. Comp. Pathol., 96, 95-100.

8. Esievo, K.A.N., Jaye, A., Andrew, J.N., Ukoha, A.I., Alafiyatayo, R.A., Eduvie, L.O., Saror, D.I., and Njoku, C.O. (1990): Electrophoresis of bovine erythrocyte sialic acid: Existence of additional band in trypanotolerant Ndama cattle. J. Comp. Pathol., 102, 357-361.

9. Shugaba, A., Umar, I.A., Omage, J.J., Ibrahim, N.D.G., Andrew, K.N., Ukoha, A.I., Saror, D.I., and Esievo, K.A.N. (1994): Biochemical differences ( $O$-acetyl and glycolyl groups) in erythrocyte surface sialic acids of trypanotolerant Ndama and trypanosusceptible Zebu cattle. J. Comp. Pathol., 110, 91-95.

10. Esievo, K.A.N., and Saror, D.I. (1991): Immunochemistry and immunopathology of animal trypanosomiasis: A review. Protozool. Abstr., 7, 337-345.

11. Esievo, K.A.N., Omage, J.J., Ibrahim, N.D.G., Umar, I.A., and Saror, D.I. (1994): Role of lactose in the control of cattle trypanosomiasis: VIth Congress of the International Society for Animal Clinical Biochemistry, August, 2-6; Guelph, Ontario, Canada.

12. Ibrahim, N.D.G., Umar, I.A., Omage, J.J., Shugaba, A., Kadima, K.B., Igbokwe, I.O., Agbede, R.I.S., Njoku, C.O., Saror, D.I., and Esievo, K.A.N. (1997): Studies on contributory role of Kupffer cell lectin in the erythrophagocytosis of acute ruminant trypanosomiasis T. vivax. J. Clin. Biochem. Nutr. (submitted).

13. Umar, I.A., Ameh, D.A., and Esievo, K.A.N. (1998): Normal plasma lactose concentration and kinetics of intravenously infused lactose in cattle. Res. Vet. Sci., 65, 1-4.

14. Umar, I.A., Omage, J.J., Shugaba, A., Igbokwe, I.O., Ibrahim, N.D.G., Kadima, K.B., Ameh, D.A., Kwanashie, H.O., Agbede, R.I.S., Saror, D.I., and Esievo, K.A.N. (1998): Effects of

Vol. 27, No. 1, 1999 
acute bovine trypanosomiasis $T$. vivax on plasma kinetics of intravenously administered lactose. Vet. Parasitol., 74, 173-178.

15. Umar, I.A. (1997): Effect of acute T. vivax infection on plasma kinetics of intravenously administered lactose and the effect of the lactose on trypanosomal anaemia in Zebu cattle. Ph. D. Thesis, Ahmadu Bello University, Zaria, Nigeria.

16. Woo, P.T.K. (1969): The haematocrite centrifuge technique for detection of trypanosomes in blood. Can. Zool., 47, 921-923.

17. Schales, O., and Schales, S.S. (1941): A simple and accurate method for the determination of chloride in biological fluids. J. Biol. Chem., 140, 979-984.

18. Monica, C. (1987): Medical Laboratory Manual for Tropical Countries, 2nd ed., ELBS, Pitman Press Ltd., Great Britain.

19. Feldman, B.F., and Rosenberg, D.P. (1981): Clinical use of anion gap and asmolal gaps in veterinary medicine. J. Am. Vet. Med. Assoc., 178, 396-398.

20. Murray, M., and Dexter, T.M. (1988): Anaemia in bovine trypanosomiasis: A review. Acta Tropica, 45, 389-432.

21. Nok, A.J., Esievo, K.A.N., Ukoha, A.I., Ikadiobi, C.O., Baba, J., Tekdek, B., and Ndams, I.S. (1992): Kidney $\mathrm{Na}^{+}-\mathrm{K}^{+}$ATPase: A kinetic study in rats during chronic infection with T. congolense. J. Clin. Biochem. Nutr., 13, 73-79.

22. Coles, E.H. (1986): Veterinary Clinical Pathology, 4th ed., W.B.S. Saunders Co., Philadelphia.

23. Stephen, P.D. (1985): Disorders of fluid, acid-base and electrolyte balance, in Medical Emergencies, ed. by Roberts, G.S., Churchill Livingstone, New York.

24. Blood, D.C., Radostits, O.M., and Henderson, J.A. (1986): Disturbance of body fluids, electrolytes and acid-base balance, in Veterinary Medicine. A Text Book of Diseases of Cattle, Sheep, Pigs, Goats and Horses (6th ed.), Pittman Press Ltd., Great Britain, pp. 61-67.

25. Maxwell, M.H., and Kleennan, C.R. (1980): Clinical Disorders of Fluids and Electrolyte Metabolism (3rd ed.), McGraw-Hill, New York.

26. Fiennes, K.T.W., Jones, E.R., and Law, S.G. (1946): The course and pathology of Trypanosoma congolense (Broden Disease of cattle). J. Comp. Pathol., 56: 1-22.

27. Sadun, E., Johnson, A., Nagle, R., and Duxbury, R. (1973): Experimental infections with west African trypanosomiasis. V: Preliminary parasitology, clinical, haematological, serological and pathological observations in rhesus monkeys infected with T. rhodensiense. Am. J. Trop. Med. Hyg., 22, 283-330.

28. Murray, M. (1974): The pathology of African trypanosomiasis, in Progress in Immunology 114, ed. by Brent, L., and Holbrown, J., Moth Holland Publishing Co., Amsterdam, pp. $181-197$.

29. Ogunsami, A.O., Akpavie, S.O., and Anosa, V.O. (1994): Serum biochemical changes in West African dwarf sheep experimentally infected with T. brucei. Rev. Med. Vet. Trop., 47, 195-200.

30. Emmett, M., and Marins, R.G. (1977): Clinical uses of anion gaps. Medicine, 45, 11-20.

31. Madias, N.E., Ayus, J.C., and Androque, H.J. (1979): Increased anion gap in metabolic alkalosis: The role of plasma proteins equivalence. N. Engl. J. Med., 300, 1421-1423.

32. Androque, H.J., Brensilver, J., and Madias, N.E. (1978): Changes in the plasma anion gap during chronic metabolic acid-base disturbances. Am. J. Physiol., 235, F291-F297. 